\title{
Biodiesel production from olive pomace
}

\author{
Nezihe Ayas ${ }^{\mathrm{a}, *}$, Tuba Elcin Cetin ${ }^{\mathrm{a}}$, Senay Ongoren ${ }^{\mathrm{a}}$, Zeynep Dincer ${ }^{\mathrm{a}}$ \\ ${ }^{a}$ Eskişehir Technical University, Faculty of Engineering, Department of Chemical Engineering, 2 Eylul Campus, 26555, Eskişehir, \\ Turkey
}

\begin{abstract}
Within the scope of this research, biodiesel production from olive pomace oil (OPO) was investigated. Esterification and transesterification reactions were carried out using a microwave synthesis unit in the presence of $\mathrm{H}_{2} \mathrm{SO}_{4}$ and $\mathrm{KOH}$ as a catalyst, respectively. The acidity index (AI) of the oil was reduced from 20 to $0.78 \mathrm{mg} \mathrm{KOH} / \mathrm{g}$ oil by an esterification reaction to avoid saponification during the transesterification process. Suitable esterification reaction parameters were determined as $65^{\circ} \mathrm{C}$, for 40 minutes with a methanol:oil molar ratio of $8: 1$ in the presence of $2.5 \%$ (wt. \%) catalyst $\left(\mathrm{H}_{2} \mathrm{SO}_{4}\right)$. The highest fatty acid methyl ester (FAME) content of the biodiesel (98.56\%) was determined by the transesterification at $65^{\circ} \mathrm{C}$ for $5 \mathrm{~min}$, using a 7:1 methanol:oil molar ratio, and $1.5 \mathrm{wt} \% \mathrm{KOH}$ catalyst. Found results are consistent with the EN14214 standard.
\end{abstract}

Keywords: Olive pomace, olive pomace oil, esterification, transesterification, biodiesel, microwave synthesis unit

\section{Introduction}

Energy requirement arises day by day because of the increasing population and developing industry. Currently, the energy requirement is fulfilled by fossil fuels, which cause climate change and environmental pollution. The greenhouse gas emissions, especially $\mathrm{CO}_{2}$, caused a search to start for renewable energy sources [1]. Biodiesel is one of the renewable energy sources. There are a number of methods to synthesize biodiesel: pyrolysis, dilution, microemulsion, and transesterification [2]. Transesterification process is an old and well-known technology for synthesis of biodiesel from animal, vegetable and waste oils [3]. Esterification reaction (Eq. 2) is carried out prior to the transesterification reaction (Eq. 1) in order to reach the desired acidity value which is lower than $1 \mathrm{mg} \mathrm{KOH} / \mathrm{g}$ [4].

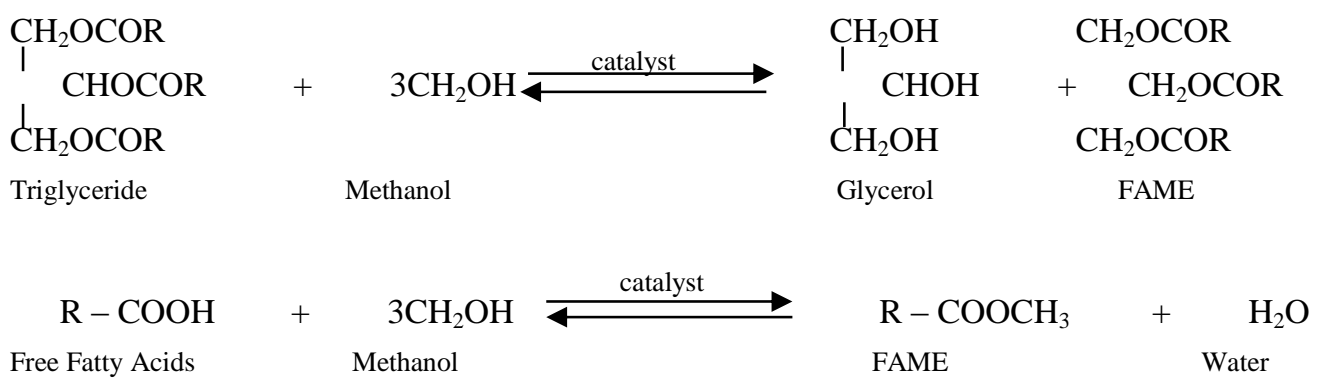

Turkey has a big potential of olive oil production and around 250 thousand tons olive pomace per year [5]. Approximately 30 thousand tons of OPO are extracted annually. There are several published papers about the utilization of OPO for biodiesel. Diógenes Hernández et al. obtained biodiesel with the yield of $94.7 \%$ from pomace oil by a transesterification reaction, which was performed using methanol:oil ratio of

*Manuscript received 02 15, 2018; revised 03 26, 2018.

Corresponding author. Tel.: +905334369600; E-mail address: neziheayas@ gmail.com

doi: 10.12720/sgce.8.3.320-324 
2:1, for $60 \mathrm{~min}$, and with $0.54 \% \mathrm{KOH}$ catalyst (wt.catalyst/wt.oil\%) [6]. Antonio Lama-Muñoz et al. determined the optimum esterification reaction conditions as 6:1 methanol:oil molar ratio in the presence of $1 \% \mathrm{H}_{2} \mathrm{SO}_{4}$ catalyst (wt.\%), for $60 \mathrm{~min}$ then carried out transesterification reaction using 6:1 methanol:oil volumetric ratio, $1 \% \mathrm{NaOH}$ catalyst (wt.\%) for 80 min with the FAME content of 95\% [7]. In the study of Sinem Caynak et al., biodiesel from OPO with the FAME value of $75.67 \%$ was obtained [8]. In this study, biodiesel was obtained using a microwave synthesis unit to determine suitable reaction conditions.

\section{Materials and Methods}

\subsection{Materials}

OPO was supplied by an olive oil factory located in Turkey. Hexane, potassium hydroxide (KOH), methanol, sulfuric acid $\left(\mathrm{H}_{2} \mathrm{SO}_{4}\right)$, phenolphthalein solution, anhydrous sodium sulfate $\left(\mathrm{Na}_{2} \mathrm{SO}_{4}\right)$, diethyl ether $\left(\left(\mathrm{C}_{2} \mathrm{H}_{5}\right)_{2} \mathrm{O}\right)$ and ethanol $\left(\mathrm{C}_{2} \mathrm{H}_{6} \mathrm{O}\right)$ were purchased from Sigma Aldrich and they were used without any pre-treatment.

\subsection{Equipment}

A microwave synthesis unit (Milestone Smart S) was used for esterification and transesterification reactions. In order to carry out the reactions homogeneously at a constant temperature; a magnetic stirrer and an infrared thermometer were used. The methyl ester content of the biodiesel was determined using an Agilent 6890N Gas Chromatography apparatus (GC). Pour point, cloud point and flash point measuring devices were used to determine the properties of the biofuel.

\subsection{Experimental Procedure}

\subsubsection{Properties of $O P O$}

Relative density and AI of the OPO were determined using standard methods [9].

\subsubsection{Esterification}

Esterification reactions were performed using a microwave synthesis unit in the presence of $\mathrm{H}_{2} \mathrm{SO}_{4}$ catalyst $\left(1.5-3 \%\right.$ wt.catalyst/wt.oil) at various reaction temperatures $\left(60,65,75^{\circ} \mathrm{C}\right)$, and reaction time (30, $40 \mathrm{~min})$.

\subsubsection{Transesterification}

Transesterification reactions of esterified $(0.78 \mathrm{mg} \mathrm{KOH} / \mathrm{g})$ oil were carried out using a microwave synthesis unit, in the presence of $\mathrm{KOH}$ catalyst $(1-2 \%)$, at $65^{\circ} \mathrm{C}$ constant temperature, 3-7 minutes reaction time and using different methanol:oil molar ratio of 6:1, 7:1, 8:1.

\subsubsection{Determining Properties of Biodiesel}

The density of biodiesel was determined by using a $25 \mathrm{~mL}$ pycnometer. In order to find out the FAME content of the biodiesel, it was firstly derivatized using $N$-methyl- $N$-trimethylsilyl-trifluoroacetamide at $25^{\circ} \mathrm{C}$, for $15 \mathrm{~min}$. This process is called silylation. After silylation, the FAMEs content was identified by GC equipped with a DB-5HT column (15 m, $0.32 \mathrm{~mm}$ ID $30.10 \mathrm{~lm}$ film thickness) with a flame ionization detector. The temperature program was set to heat the device from $50^{\circ} \mathrm{C}$ to $180^{\circ} \mathrm{C}$ at $15^{\circ} \mathrm{C} / \mathrm{min}$. After that, the temperature was increased to $230^{\circ} \mathrm{C}$ at $7^{\circ} \mathrm{C} / \mathrm{min}$. Finally, it was heated to $370^{\circ} \mathrm{C}$ at $10^{\circ} \mathrm{C} / \mathrm{min}$, and remained at this temperature for $20 \mathrm{~min}$ [4]. Pour point, cloud point and flash point of biodiesel were measured according to standard methods [9].

\section{Results and Discussion}

\subsection{Properties of $O P O$ and Biodiesel}

Properties of OPO and biodiesel are given in Table 1. 
Table 1. Properties of Olive Pomace Oil and Biodiesel

\begin{tabular}{|l|c|c|}
\hline & \multicolumn{2}{|c|}{ Olive Pomace Oil } \\
\hline Density $\left(\mathbf{g} / \mathbf{c m}^{\mathbf{3}}\right)$ & \multicolumn{2}{|c|}{20} \\
\hline AI $(\mathbf{m g}$ KOH/g sample) & Biodiesel & Reference Values \\
\hline & 0.886 & $0.86-0.9$ \\
\hline Relative density at $\mathbf{2 5}^{\circ} \mathbf{C}$ & 98.56 & $>96.5$ \\
\hline FAMEs (\%) & $177^{\circ} \mathrm{C}$ & $>120$ \\
\hline Flash Point & $-5^{\circ} \mathrm{C}$ & $(-5)-(17)$ \\
\hline Cloud Point & $-10^{\circ} \mathrm{C}$ & $(-15)-(16)$ \\
\hline Pour Point & & \\
\hline
\end{tabular}

Properties of biodiesel are in line with the standard of EN14214 [10, 11].

\subsection{Effect of Reaction Parameters on The Esterification}

AIs of the oil are plotted against catalyst ratio, temperature and reaction time (Fig.1) in order to avoid saponification during transesterification.

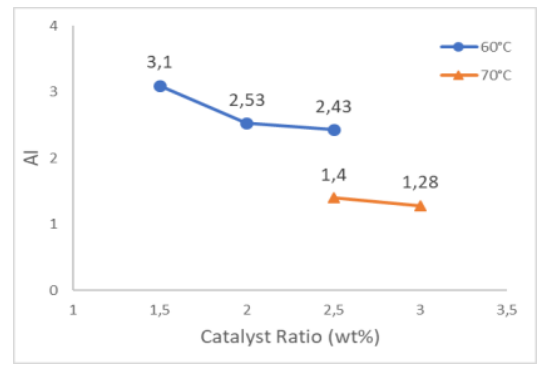

(a)

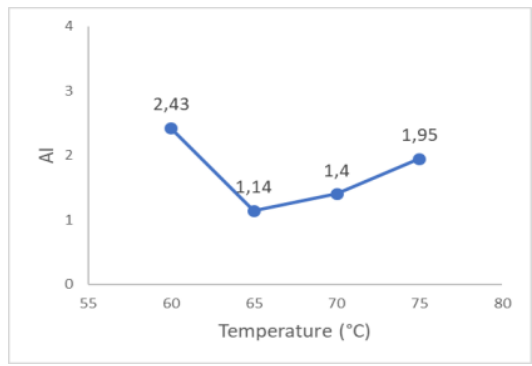

(b)

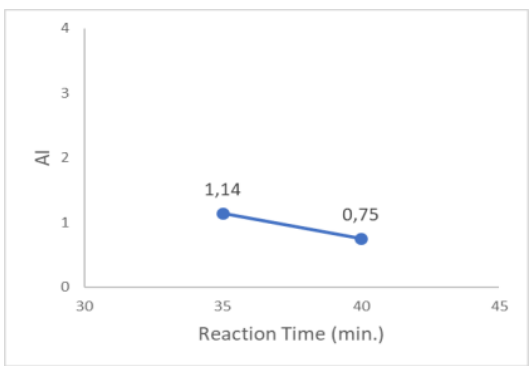

(c)

Fig. 1. Effect of (a) catalyst ratio @ 8:1 methanol:oil, 35 min, 60-70 ${ }^{\circ} \mathrm{C}$, (b) temperature @ 8:1 methanol:oil, 2.5\% $\mathrm{H}_{2} \mathrm{SO}_{4}, 35 \mathrm{~min}$, (c) reaction time on $\mathrm{AI} \mathrm{mg} \mathrm{KOH} / \mathrm{g}$ sample @ 8:1 methanol:oil, $2.5 \% \mathrm{H}_{2} \mathrm{SO}_{4}, 65^{\circ} \mathrm{C}$

Fig.1a. illustrates that $\mathrm{AI}$ decreases with the catalyst ratio and temperature. The lowest $\mathrm{AI}$ (2.43) value was achieved at $60{ }^{\circ} \mathrm{C}$ which is extremely higher than the desired value. There is no significant difference between the AIs achieved at $70^{\circ} \mathrm{C}$ using $2.5 \%$ (AI: 1.4 ) and 3\% (AI: 1.28) catalyst ratios. Therefore, further experiments were carried out using a catalyst ratio of $2.5 \%$.

According to Fig. 1b. AI decreases with temperature until $65^{\circ} \mathrm{C}$. With further increments in temperature, AI values started to increase because of the boiling point of methanol. As a consequence, subsequent experiments were carried out at $65^{\circ} \mathrm{C}$.

Effect of reaction time on the AI was presented in Fig. 1c. The AI decreases from 1.14 to 0.75 when the time increased from 35 to 40 minutes. The aim of this reaction is having an AI less than $1 \mathrm{mg} \mathrm{KOH} / \mathrm{g}$, so 40 minutes was determined to be the most suitable reaction time. 


\subsection{Effect of Reaction Parameters on Transesterification Reaction}

FAME content of biodiesel was determined according to catalyst ratio, reaction time and methanol:oil ratio (Fig. 2).

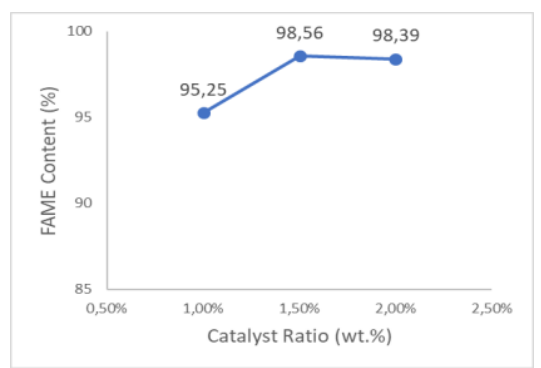

(a)

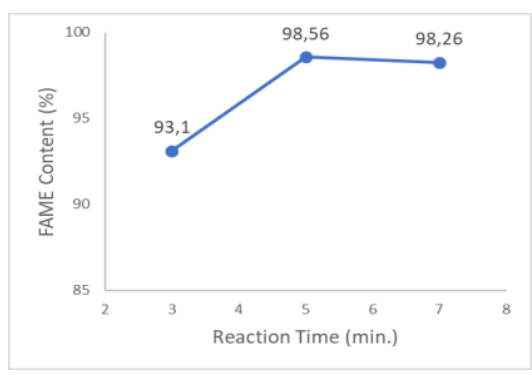

(b)

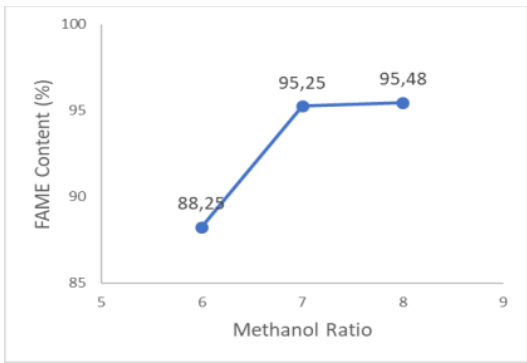

(c)

Fig. 2. Effect of (a) catalyst ratio @ $65^{\circ} \mathrm{C}, 7: 1$ methanol:oil, 5 min, (b) Reaction time @ 65 ${ }^{\circ} \mathrm{C}, 7: 1$ methanol:oil, $1.5 \% \mathrm{KOH}$, (c) methanol:oil ratio on FAME content of biodiesel @ $65^{\circ} \mathrm{C}, 1 \% \mathrm{KOH}, 5$ minutes reaction time

Fig. 2a. illustrates that the maximum FAME content of biodiesel (98.56\%) is achieved when $1.5 \%$ $\mathrm{KOH}$ is used.

As it is seen in Fig. 2b the FAME content of biodiesel decreases after 5 min since the transesterification reaction is reversible. As a result, the highest value of FAME (98.56\%) was achieved in $5 \mathrm{~min}$.

According to Fig. 2c FAME content of the biodiesel increases with the methanol:oil ratio. There is no significant difference between the FAME contents of 7:1 and 8:1 methanol:oil ratios. The most suitable value of methanol:oil ratio was found as 7:1 because of the cost of the methanol.

\section{Conclusion}

OPO with a high free fatty acid content was used as a promising feedstock for biodiesel production by applying esterification and then transesterification reactions. Because of the high AI of the OPO, the esterification reaction was carried out to lower its AI in order to avoid saponification occur during transesterification reaction. The suitable esterification parameters were determined as $2.5 \% \mathrm{H}_{2} \mathrm{SO}_{4}, 65^{\circ} \mathrm{C}$, for $40 \mathrm{~min}$, with an 8:1 methanol:oil molar ratio with the result of $0.75 \mathrm{mg} \mathrm{KOH} / \mathrm{g}$ oil of AI. In order to obtain biodiesel, the esterification reaction was followed by transesterification at $65^{\circ} \mathrm{C}$, for 5 min with 7:1 methanol:oil ratio in the presence of $1.5 \% \mathrm{KOH}$ catalyst. FAME content, density, flash point, cloud point and pour point of the biodiesel were found to be as $98.56 \%, 0.886 \mathrm{~g} / \mathrm{cm}^{3}, 177,-10,-5^{\circ} \mathrm{C}$ which are in good agreement with the EN14214. Even though there are a number of studies on OPO in the literature, none of them are in line with the standard values. 


\section{Acknowledgment}

This study was supported by TUBITAK 2209-B Industry-Focused Undergraduate Thesis Programme under the grant number 1139B411602173. We are also grateful to Vildan Aker and Fahriye Dönmez for their kind help.

\section{References}

[1] World Meteorological Organisation, Green House Gas Bulletin, The State of Greenhouse Gasses in the Atmosphere Based on Global Observation through 2015, No 12, October 2016

[2] Alptekin E, Çanakçı M. Biyodizel ve Türkiye'deki Durumu. Journal of Mühendis ve Makine, 2006; 47(561):57-64.

[3] Fidan MS, Alkan E. Bitkisel Hammaddelerden Elde Edilen Biyodizelin Alternatif Enerji Kaynağı Olarak Kullanılması, Gümüşhane Üniversitesi Fen Bilimleri Enstitüsü Dergisi, 2014; 4(2):144-160.

[4] Ayas N, Yilmaz, Ö. Catalytic esterification and transesterification reaction of high acidic value waste oil by microwave heating. Environmental Progress \& Sustainable Energy, 2014; 34(2):575-581.

[5] TC Milli Eğitim Bakanlığı. Gıda Teknolojisi, Pirina Yağı Modülü, Code: 541GI0154, Ankara (2011).

[6] Hernández D, Astudillo L, Gutiérrez M, Tenreiro C, Retamal C, Rojas C. Biodiesel production from an industrial residue: Alperujo. Industrial Crops and Products, 2013; 495-498.

[7] Lama-Muñoz A, Álvarez-Mateos P, Rodríguez-Gutiérrez G, Durán-Barrantes MM, Fernández-Bolaños J. Biodiesel Production from Olive - Pomace Oil of Steam - Treated Alperujo, Biomass and Bioenergy, 2014; 443 - 450.

[8] Çaynak S, Gürü M, Biçer A, Keskin A, İçingür Y. Biodiesel production form Pomace oil and improvement of its properties with synthetic manganese additive, Fuel, 2009; $534-538$.

[9] United States Pharmacopeia Convention. The United States Pharmacopeia: USP (22th edition), Rockville: United States Pharmacopeia Convention. 1990

[10] Romero R, Martínez SL, Natividad R. Biodiesel production by using heterogeneous catalysts. In Alternative fuel. InTech.; 2011.

[11] Barabás I, Todoruț IA. Biodiesel quality, standards and properties. In Biodiesel-quality, emissions and by-products. InTech.; 2011. 